\title{
New records of Fannia Robineau-Desvoidy (Diptera: Fanniidae) collected on pig carrion in Portugal with additional data on the distribution of $F$. conspecta Rudzinski, 2003
}

\author{
Andrzej Grzywacz \& Catarina Prado e Castro
}

\begin{abstract}
Grzywacz, A. \& Prado e Castro, C. 2012: New records of Fannia RobineauDesvoidy (Diptera: Fanniidae) collected on pig carrion in Portugal with additional data on the distribution of $F$. conspecta Rudzinski, 2003. - Entomol. Fennica 23: 169-176.

During a study of arthropod succession on pig carrion in Portugal eleven species of Fannia Robineau-Desvoidy (Diptera: Fanniidae) were collected, of which $F$. aequilineata Ringdahl, F. armata (Meigen) and F. pusio (Wiedemann) are new records for Portugal, $F$. consepcta Rudzinski and $F$. lineata (Stein) are newly recorded for the whole Iberian Peninsula and F. tunisiae Chillcott is for the first time reported from the continental Europe. Additional information on the occurrence of $F$. conspecta in Czech Republic, Denmark, Greece, and Southern Russia are presented. The number of Fanniidae distributed throughout the Iberian Peninsula raises from 35 to 38 and the number of species reported from Portugal raises from 11 to 17 .
\end{abstract}

A. Grzywacz, Department of Animal Ecology, Institute of Ecology and Environmental Protection, Nicolaus Copernicus University, Gagarina 9, 87-100 Torun, Poland; E-mail: hydrotaea@gmail.com

C. Prado e Castro, Centre for Environmental Biology, Department of Animal Biology, Faculty of Sciences, University of Lisbon. Ed. C2, Campo Grande. 1749-016 Lisbon, Portugal; E-mail: cbcastro@fc.ul.pt

Received 28 December 2011, accepted 20 March 2012

\section{Introduction}

Fanniidae is a small dipteran family with worldwide distribution and the highest species diversity in temperate zones (Rozkošný et al. 1997). Recent phylogenetic studies based on morphological (Domínguez \& Roig-Juñent 2008) and molecular (Kutty et al. 2008, 2010) data have proved well supported monophyly of the family. Most of the 300 described species occur in Holarctic region (Carvalho et al. 2003). However, recently new species have been described from $\mathrm{Pa}$ laearctic (e.g. Wang et al. 2007a, b, Pont \& Vik- hrev 2009) as well as Neotropical region (Wendt \& Carvalho 2007, Domínguez \& Aballay 2008, Quiroga \& Domínguez 2010, Wendt 2010). Furthermore, a new genus and five species of Fannia are considered for the description from New Zealand (Holloway 1984, Domínguez \& RoigJuñent 2008). From the four recognised genera, American Euryomma Stein with the cosmopolitan E. peregrinum (Meigen), cosmopolitan Fannia Robineau-Desvoidy, Holarctic Piezura Rondani and the Australian endemic Australofannia Pont, the straight majority of the species belong to the genus Fannia. Chillcott (1961a), 
based mainly on the morphology of male genitalia, have assigned Nearctic representatives of Fannia to the 11 groups of species, dividing also six of these groups into the 15 subgroups in total. The proposed classification has been accepted by many authors, and recently revisions and updated definitions of some species groups were published (e.g. Rozkošný et al. 1997, Couri 2005, Wang et al. 2007a, b), also monophyly of some groups was proved in the phylogenetic study of Domínguez and Roig-Juñent (2008).

Adult Fanniidae are associated with woodland areas and are relatively rare in open habitats, however, few species are closely related with human estates being thus important for human from medical and hygienic point of view. Few species of Fannia were recognized as vectors of Dermatobia hominis (Linnaeus Jr.) (Diptera: Oestridae) (Espindola \& Couri 2004).

Larvae of Fanniidae are trimorphic saprophages developing in various types of decomposing organic matter, from decaying vegetables, animal nests to decomposing invertebrate and vertebrate carrion (Rozkošný et al. 1997). At given conditions some of them are involved in myiasis cases (Zumpt 1965). The association of larval development of some species with decomposing bodies is well known (Byrd \& Castner 2010) and have aroused particular interest in those species as valuable forensic indicators (Benecke \& Lessig 2001, Matuszewski et al. 2010). The most commonly found species in forensic investigations and carrion succession experiments are $F$. canicularis (Linnaeus), $F$. manicata (Meigen), F. pusio (Wiedemann) and $F$. scalaris (Fabricius). Even if larvae do not develop for example in decomposing animal tissues, adult flies frequently are attracted to such lures. The use of diverse traps in such experiments (Espindola \& Couri 2004, Hwang \& Turner 2005, Domínguez \& Aballay 2008, Prado e Castro et al. 2009) allow to collect extensive material for faunistic (Prado e Castro \& García 2010, Prado e Castro et al. 2010a, b, Carles-Tolrá \& Prado e Castro 2011) and taxonomic (Domínguez \& Aballay 2008, Quiroga \& Domínguez 2010) studies.

Currently 84 species of Fanniidae have been recorded from Europe, of which 81 belongs to the genus Fannia (Rudzinski 2003, Pont 2004).
From the Iberian Peninsula 35 species of Fanniidae have been recorded to date, of which 33 are classified in the genus Fannia (Pont 2004, Carles-Tolrá \& Páez 2010). Only 11 Fanniidae species were known from Portugal prior to this study (Pont 2004). Ten of them, F. canicularis, F. coracina (Loew, 1873), F. incisurata (Zetterstedt, 1838), F. leucosticta (Meigen, 1838), F. lepida (Wiedemann, 1817), F. lustrator (Harris, 1780), F. manicata, F. monilis (Haliday, 1838), F. scalaris and $F$. sociella (Zetterstedt, 1845), belong to the genus Fannia and the eleventh, E. peregrinum (Meigen, 1826), is the only Palaearctic representative of Euryomma. The aim of this paper is to report new records of Fannia for Portugal, as well as additional data on the occurrence of one recently described species in West Palaearctic.

\section{Material and methods}

From October 2006 to August 2007 a modified version of Schoenly trap (Prado e Castro et al. 2009) was used to study insect fauna associated with pig carrion. In four different seasons (autumn, winter, spring and summer) one piglet $(\approx 8$ kg weight) was used in separate experiments of 10 weeks each. The traps were checked daily during the first 23 days, afterwards every 2,3 or 5 days until the end of each period. The collected material was preserved in $70 \%$ ethyl alcohol. The study was performed in the Instituto Superior de Agronomia, Tapada da Ajuda, Lisbon, Portugal, a small woodland park inside an urban perimeter, at an altitude of $80 \mathrm{~m}$ a.s.1.

The material has been collected by the second author and identified by the first author basing on the keys of d'Assis-Fonseca (1968) and Rozkošný et al. (1997). Species identification of selected series of all species was verified based on the collections of the Natural History Museum (London, UK) and Natural History Museum of Denmark (Copenhagen, Denmark).

Because of difficulties in the identification of females of the genus Fannia in case of small series of specimens represented exclusively by females, records are presented with some reservations with '?' marks.

For detailed study of male genitalia the abdomen was removed and boiled in $10 \% \mathrm{KOH}$ solu- 
tion for $10 \mathrm{~min}$. The abdomen was transferred to glycerine to separate postabdominal structures for detailed observation. After examination, genitalia and the rest of the abdomen were placed in glycerine in a small microvial and pinned with the appropriate specimen. Photographs were taken with a Nikon 8400 digital camera mounted on a Nikon Eclipse E200 microscope (Nikon Corp., Tokyo, Japan).

Identified material was deposited in the collections of the Department of Animal Biology, University of Lisbon (Portugal) and Department of Animal Ecology, Nicolaus Copernicus University (Poland).

\section{Results and discussion}

In total, 20,144 adult Diptera representing 39 families were collected in this study. Fanniidae were represented by 1,654 specimens, all belonging to the genus Fannia. Among the studied material, a total of 11 species were identified, of which six species are newly recorded for Portugal, two of them are new records for the whole Iberian Peninsula and one species is for the first time recorded from the European mainland.

\subsection{Fannia aequilineata Ringdahl, 1945}

Material examined: 23.X.2006, 19; 26.X.2006, 4우; 29.X.2006, 1; 12.XI.2006, 19; 24.XI. 2006, 1 \&; 12.XII.2006, 1 ; ; 26.II.2007, 1 ; ; 18.30.IV.2007, 44오오, 16今ð; 3.-9.V.2007, 23 오오, 6 ๙ో; 11.V.2007, 1q; 13.V.2007, 19; 15.V.2007, 1 ; 23.V.2007, 4; 26.V.2007, 1 + , 1ठ; 29.V. 2007, 5ㅇ; 1.VI.2007, 1 9 ; 4.VI.2007, 2 q ; 13.VI.2007, $3 q$ 우 30.VI.-5.VII.2007, 34우어,

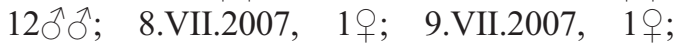
17.VII.2007, 1q; 24.VII.2007, 2qo; 26.VII. 2007, 2 우; 28.VII.2007, 1; 30.VII.2007, 1 ; 3.VIII.2007, 19; 15.VIII.2007, 2 $\circ$; 18.VIII. 2007, 3우; 21.VIII.2007, 1ㅇ; 24.VIII.2007, 1 ; 27.VIII.2007, 1 q, $1 \widehat{\jmath}$.

Reported in Europe from Czech Republic, Denmark, Germany, Great Britain, France, Hungary, Ireland, Malta, Spain, Slovak Republic, Switzerland and Sweden, also known from North Africa (Pont, 2004). First record for Portugal.
Larvae reared from dung, blackbird's nest, wasp's nest, wood detritus, rotting wood and fungi (Rozkošný et al. 1997). Adults associated with sap runs (Rozkošný et al. 1997) and attracted to decomposing liver (Hwang \& Turner 2005).

\subsection{Fannia armata (Meigen, 1826)}

Material examined: 18.-22.IV.2007, 5우; 5.VII.2007, 1 \%; 9.VIII.2007, 1q; 18.VIII.2007, 1ㅇ; 24.VIII.2007, 5 우; 27.VIII.2007, 2 우오.

Distributed throughout Europe (Rozkošný et al. 1997) also known from Arabian Peninsula, Armenia, Azerbaijan, Georgia, Iran, Iraq, Israel, Jordan, Turkey, Lebanon, North Caucasus, Sinai Peninsula (Egypt) and Syria (Pont 2004). First record for Portugal. Larvae reared from dung, rotting wood and fungi, adults secretopheges (Rozkošný et al. 1997).

\subsection{Fannia canicularis (Linnaeus, 1761)}

Material examined: 21.X.2006, 19; 22.X.2006, 1; 25.-29.X.2006, 30우 ; 1.XI.2006, 2우 ; 3.XI.2006, 19 ; 5.XI.2006, 19 ; 16.XI.2006, 1 ; 18.XI.2006, 2우; 27.XI.2006, 19; 9.XII.2006, 1 ; ; 18.XII.2006, 1 ; ; 2.II.2007, 7 우; 8.II.2007, 1ㅇ; 9.II.2007, 1; 11.II.2007, 1ㅇ; 13.II.2007, 2우; 15.II.2007, 4우; 19.II.2007, 4우; 23.II.2007, 7q $q$; 26.II.2007, 1q; 1.III.2007, 3 우; 4.III.2007, 2 우; 10.III.2007, 1 ; 17.IV.-

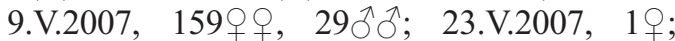
26.V.2007, 4우; 29.V.2007, 3 우 ; 13.VI.2007, 1; 15.VI.2007, 1; ; 29.VI.-11.VII.2007,

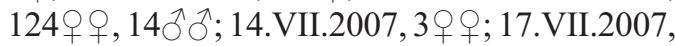
2 우; 26.VII.2007, 5우; 6.VIII.2007, 19 ; 18.VIII.2007, 4우; 27.VIII.2007, 2 우. Among examined specimens, in two females (10.VII.2007 and 18.VIII.2007) unusual two anderodorsal $(a d)$ and two posterodorsal $(p d)$ setae on the mid tibia were found.

Almost cosmopolitan species (Rozkošný et al. 1997) known from all biogeographic regions (Pont 2004). Known from peninsular Portugal, Azores and Madeira (Pont 2004) prior to this study. Larvae develop in various types of organic matter, including decomposing carrion and hu- 
man bodies, it is also involved in myiasis cases (Zumpt 1965), which makes this species of particular interest from medical and hygienic point of view.

\subsection{Fannia conspecta Rudzinski, 2003} (Figs. 1-2)

Material examined: 24.IV.2007, 1ठ̋; 2.VII.2007, 1ठ; 24.VII.2007, 1 ऽ. Female of $F$. conspecta has not been described to date. Among the collected material, two specimens (23.IV.2007, 1\%; 24.IV.2007, 1 ) ) fall in the key of Rozkošný et al. (1997) to the character couplet no. 16, but because of palpi broader than $2 / 3$ of antennal flagellomere and distinct brown stripes on thorax, we are unable to state if they could be assigned as aberrant females or F. subpubescens Collin, 1958 or representatives of other species, e.g. F. conspecta.

Despite presenting detailed illustrations of male genitalia, Rudzinski (2003) did not include drawings of whole hypandrium. Therefore we provide additional illustrations presenting broad, heavily sclerotised ninth sternum with inwardly projecting hypandrial arms as well as peculiar elongated aedeagus and postgonites (Figs $2 \mathrm{a}-\mathrm{c}$ ).

Prior to this study, F. conspecta was reported in the literature only from Hessen in Germany, from where it was described by Rudzinski (2003), but was omitted in the Fauna Europaea checklist (Pont 2004). The records of the present study are the first ones for Portugal and the Iberian Peninsula. Thanks to the kindness of Dr. Verner Michelsen, who granted us access to the specimens of $F$. conspecta identified by him (deposited in the collection of the Zoological Museum, Copenhagen, Denmark) as well as information made available for us by Mr. Nikita Vikhrev (pers. comm.), we report here occurrence of this rare species from distant localities. Label data of voucher specimens from Zoological Museum are given verbatim with '//' representing a line change and ';' a change in label. F. conspecta was collected from the following localities:

- Czech Republic: CZ: Bílina - Jirásek III, MT/ / Phragmitetum, 310 m, 1998// 50³3`35`N, $13^{\circ} 47^{`} 44^{\prime} \mathrm{E} / /$ leg. Barták, 14.v.-23.vii.

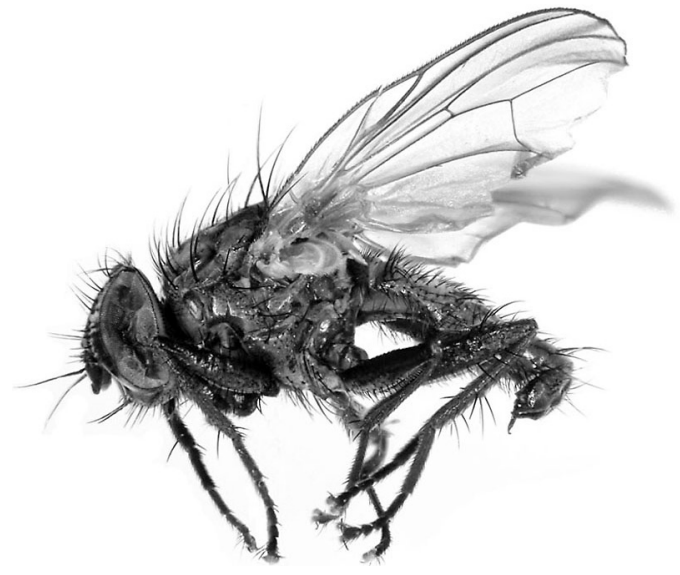

Fig. 1. Fannia conspecta male, lateral view.

- Denmark: Danmark WJ Tipperne// Juni 1973/ / E. Rald leg.; Dania, NEZ UB38// Ganløse Orned// 7/8 1987// leg. Stig Andersen; Dania: NEZ, UB47// Gladsaxe (Skolehave)// 3.VI.1987// V. Michelsen; Dania: NEZ, UB46// Kalvebod Fælled// 20.VIII.1987// V. Michelsen; Dania: NEZ, UB47// Gladsaxe (Skolehave)// 26.V.1988// V. Michelsen,

- Greece: GREECE: IPIROS// Peristéri Mts, 12-2,100 m// 24-28.V.1994// V. MichelsenColl. ZMUC; Helvetia// Delémont// 10.10. 1981// S. Andersen,

- Southern Russia: Krasnodar reg., Sochi distr., Imeritinskaya lowland $\left(43.39^{\circ} \mathrm{N} 40.00^{\circ} \mathrm{E}\right)$, 23.IV.2007, 1ठ; 30.IX.2008, 1ठ, (1ㅇ?); 2.X.2008, 1§ं; N. Vikhrev leg.

\subsection{Fannia lepida (Wiedemann, 1817)}

Material examined: 2.II.2007, 1q; 11.II.2007, 1 ; 13.II.2007, 19 ; 15.II.2007, 1 q; 19.IV.2007, 1 ; 20.IV.2007, 6ㅇ; 22.IV.2007, 1q; 23.IV. 2007, 6우; 25.IV.2007, 1; 26.IV.2007, 1ㅇ 28.IV.2007, 2 q + ; 4.V.2007, 1 \% ; 4.VII.2007, 1 ; 9.VII.2007, 19. Among examined material, one female (4.V.2007) possess parafacials covered with short hairs, characteristic for the females of canicularis group species.

Saprophagous forest species with Holarctic distribution (Rozkošný et al. 1997) and according to Pont (2004) occurring also in Oriental Region. Known from Portugal (Rozkošný et al. 1997, 

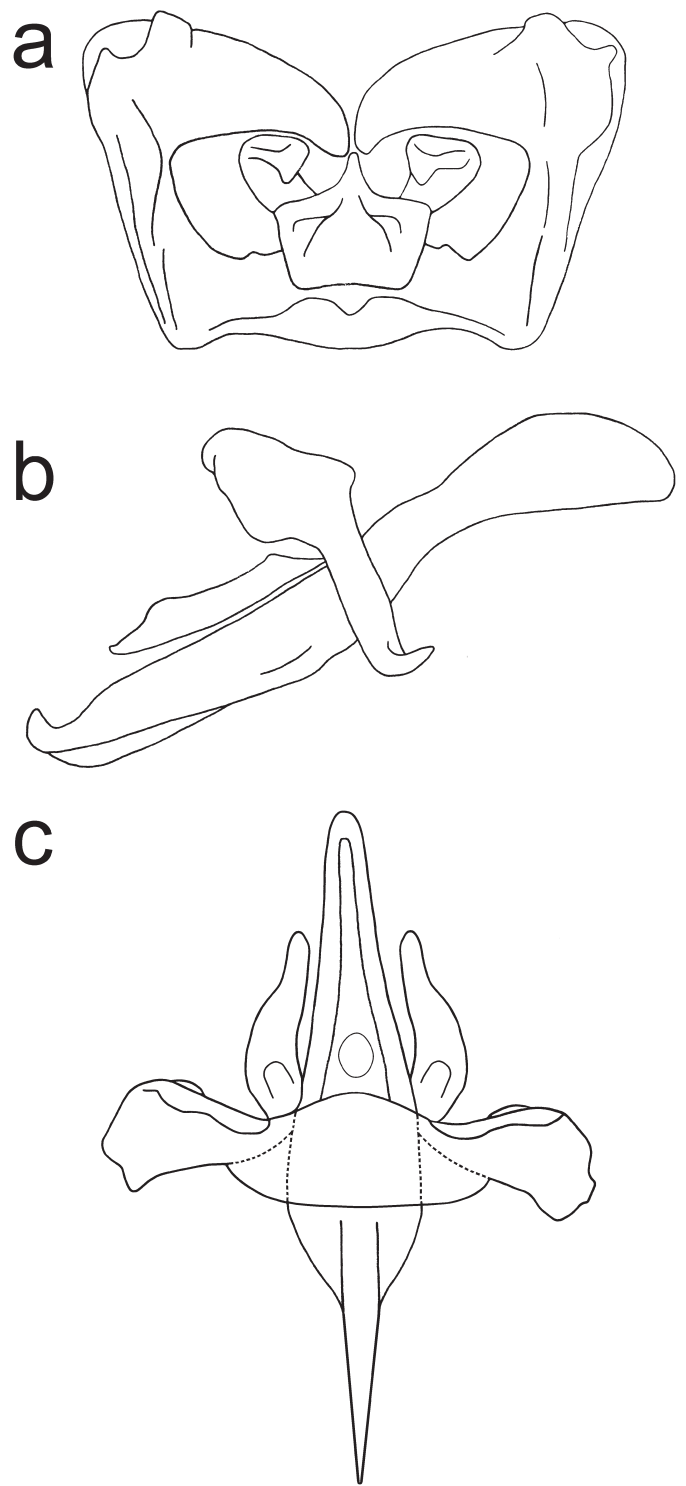

Fig. 2. Fannia conspecta. - a. Male hypandrium, ventral view. - b. Male hypandrium, lateral view. - c. Male hypandrium, antero-ventral view.

Pont 2004), however omitted in Pont \& Baéz (2002).

\subsection{Fannia leucosticta (Meigen, 1838)}

Material examined: 26.-29.X.2006, 16우 20.IV.2007, 2qo; 22.-26.IV.2007, 66ㅇ; 28.30.IV.2007, 7우; 5.V.2007,2ㅇ; 6.V.2007, 1q; 4.VI.2007, 1우 2.-6.VII.2007, 77 우.
Synanthropic species with almost cosmopolitan distribution (Rozkošný et al. 1997), but absent from South America (Carvalho et al. 2003). Already known from Portugal. Adults attracted to carrion (Miralbes 2002) and larvae found in decomposing organic matter and carrion (Tantawi et al. 1996).

\subsection{Fannia lineata (Stein, 1895) (?)}

Material examined: 22.IV.2007, 2우; 2.VII.2007, 1 ㅇ․

Rare European species, reported from Austria, Bulgaria, Czech Republic, Finland, Germany, Great Britain, Italy, Central Russia, Sweden and Switzerland (Pont 2004). First record for Portugal and whole Iberian Peninsula, though because only few specimens were collected and males were absent in the material, this record should be treated with some reservations. Larvae bred from nests of birds, also found in a rabbit burrow and carrion (Rozkošný et al. 1997).

\subsection{Fannia monilis (Haliday, 1838)}

Material examined: 2.-5.II.2007, 8우 11.II.2007，1q；15.II.2007，1q；17.II.2007, $3 ㅇ ㅜ$ 19.II.2007, 3우; 23.II.2007, 2우, 1.III.2007, 1 9 ; 4.III.2007, 2ㅇ; 20.IV.2007, 2우; 22.IV.2007, 12우; 23.IV.2007, 10 우, 1今; 25.IV.2007, 1q; 27.IV.2007, 1 \%; 3.V.2007, 1ㅇ; 26.V.2007, 1; 1.-3.VII.2007, 3우; 5.VII.2007, 1 ㅇ․

Palaearctic distribution, known from Portugal prior to this study (Pont 2004). Adults attracted to decomposing liver (Hwang \& Turner 2005), larvae develop in decaying vegetable matter, soil, fungi, dung, nests of birds (Rozkošný et al. 1997).

\subsection{Fannia pusio (Wiedemann, 1830)}

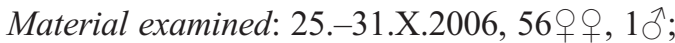
6.XI.2006, 1 ; ; 9.XII.2006, 1q; 1.III.2007, 1 ;

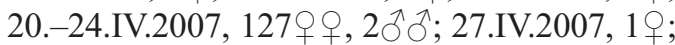
29.IV.2007, 1q; 4.V.2007, 1; 7.V.2007, 1 \% ; 26.V.2007, 1 $\odot$; 2.-5.VII.2007, 15 9 ; 26.VII. 2007, 1우. Among studied material, 우우 with 
more than one anteroventral $(a v)$ seta on hind tibia were found (7.V.2007, 1 \% with two $a v$ setae; 29.-30.X.2007, 5 우 with two or three $a v$ setae).

Known from both Americas, Pacific Region, West Africa and Mediterranean Region, recently introduced to Europe (Rozkošný et al. 1997, Carvalho et al. 2003). First record for Portugal. Adults attracted to carrion (Tullis \& Goff 1987, Carvalho et al. 2000), larvae develop in various types of decaying matter, also in human bodies (Bohart \& Gressitt 1951).

\subsection{Fannia scalaris (Fabricius, 1794)}

Material examined: 26.-28.X.2006, 4우; 2.II.2007, 8 ㅇ; 15. II.2007, 5ㅇ; 17.II.2007, 1 ㅇ 19. III.2007, 5우 26. II.2007, 2 q $ᄋ$; 1.III. 2007, 7우 ; 4.III.2007, 4우 ; 7.III.2007, 2ㅇ; 10.III.2007, 1; 18.IV.-9.V.2007, 377우우, 13ふふર; 21.V.2007, 2qㅇ; 23.V.2007, 1; 26.V. 2007, 12우; 29.V.2007, 15우; 15.VI.2007, 6우; 30.VI.-8.VII.2007, 69우, 6ふす; 14.VII. 2007, 1ㅇ; 24.VII.2007, 1ㅇ; 26.VII.2007, 5 우; 6.VIII.2007, 1 ㅇ.

Almost cosmopolitan distribution, reported from all biogeographic regions, except Australian (Pont 2004). Already known from Portugal mainland and Azores. Larvae saprophagous, reared from invertebrate and vertebrate carrion, nests of Hymenoptera, birds and mammals (Rozkošný et al. 1997), also involved in myiasis cases (Zumpt 1965). Species of particular human interest due to its medical and hygienic importance.

\subsection{Fannia tunisiae Chillcott, 1961 (?)}

Material examined: 22.X.2006, 1 \%; 28.X.2006, 1 . Among examined specimens one female (22.X.2006) possess one of the lower calypters aberrant, distinctly smaller than second one developed normally.

Prior to this study known only from Tunisia (Chillcott 1961b) and Baleares (Pont 2004). First record for Portugal and whole continental Europe. As in the case of $F$. lineata, because of lack of males in the collected material and presence of only few females, this record should be treated with some reservations.

\section{Discussion}

With 35 species of Fanniidae known from the whole Iberian Peninsula, Portuguese fauna, consisting currently of 17 reported species, of which 16 are present in the continental part, remains very small. However due to the lack of consistent collecting and sparse faunistic data any reliable conclusions about Portuguese Fanniidae fauna are restricted. At least few further records should be expected, since 19 additional species occur in Spain (Pont 2004). Fauna of Azores and Madeira, with only six species reported to date in each island, may appear to be impoverished. However, other islands present similar data, e.g. Canary Islands with seven species (Pont 2004), Sicily and Malta, each with eight species (Ebejer \& Gatt 1999).

Acknowledgments. We thank Dr. Adrian C. Pont (Oxford, UK) for confirmation of species identification of selected series of specimens, Dr. Verner Michelsen (Copenhagen, Denmark) and Mr. N. Vikhrev (Moscow, Russia) for valuable information and granting permission for the use of data concerning Fannia conspecta distribution, Dr. M. C. Domínguez (Mendoza, Argentina) for helpful comments on the manuscript, Dr. Martin J. R. Hall (London, UK) for the given help during visit in Natural History Museum. This work was supported by Fundação para a Ciência e Tecnologia through SFRH/BD/23066/2005 PhD grant for C. Prado e Castro. Work in Natural History Museum, (London, UK) received support from the SYNTHESYS Project http://www.synthesys.info/, which is financed by the European Community Research Infrastructure Action under the FP7 Integrating Activities Programme and in Zoological Museum (Copenhagen, Denmark) from the Polish Ministry of Science and Higher Education (grant no N N303 470838) for A. Grzywacz.

\section{References}

Benecke, M. \& Lessig, R. 2001: Child neglect and forensic entomology. - Forensic Science International 120: 155-159.

Bohart, G. E. \& Gressitt, J. L. 1951: Filth-inhabiting flies of Guam. - Bernice P. Bishop Museum Bulletin, Honolulu, Hawaii 204: VIII+152pp.

Byrd, J. H. \& Castner, J. L. 2010: Insects of forensic importance. - In: Byrd, J. H. \& Castner J. L. (eds.), Forensic Entomology: The Utility of Arthropods in Legal Investigations: 39-126. CRC Press, New York, NY.

Carles-Tolrá, M. \& Páez, A. V. 2010: Nuevos datos dipterológicos del Parque Natural de los Alcornocales (Cádiz, España) (Insecta, Diptera) — Boletín de la Socie- 
dad Entomológica Aragonesa (S.E.A.) 47: 369-371. [In Spanish]

Carles-Tolrá, M. \& Prado e Castro, C. 2011: Some dipterans collected on pig carcasses in Portugal (Diptera: Carnidae, Heleomyzidae, Lauxaniidae, and Sphaeroceridae). - Boletín de la Sociedad Entomológica Aragonesa (S.E.A.) 48: 233-236.

Carvalho, L. M. L., Thyssen, P. J., Linhares, A. X. \& Palhares, F. A. B. 2000: A checklist of Arthropods associated with pig carrion and human corpses in Southeastern Brazil. - Memórias do Instituto Oswaldo Cruz, Rio de Janeiro 95: 135-138.

Carvalho, C. J. B., Pont, A. C., Couri, M. S. \& Pamplona, D. 2003: A catalogue of Fanniidae (Diptera) of the Neotropical Region. - Zootaxa 219: 1-32.

Chillcott, J. G. 1961a: A revision of the Nearctic species of Fanniinae (Diptera: Muscidae). - The Canadian Entomologist 92: 14(Suppl.) 1-295.

Chillcott, J. G. 1961b: Ten New species of Fannia R.-D. (Diptera, Muscidae) from the Palaearctic and Oriental regions. - The Canadian Entomologist 93: 81-92.

Couri, M. S. 2005: An illustrated key to the adult males of Neotropical Fannia Robineau-Desvoidy belonging to pusio sub-group (Diptera, Fanniidae). — Brazilian Journal of Biology 65: 625-629.

d'Assis-Fonseca, E. C. M. 1968: Diptera: Cyclorrhapha Calyptrata section (b) Muscidae. - Handbooks for the identification of British Insects, Royal Entomological Society of London, London, UK. 119 pp.

Domínguez, M. C. \& Aballay, F. 2008: A new species of the genus Fannia Robineau-Desvoidy (Diptera: Fanniidae) collected on pig carrion in Mendoza, Argentina. - Annales Zoologici 58: 819-824.

Domínguez, M. C. \& Roig-Juñent, S. A. 2008: A phylogeny of the family Fanniidae Schnabl (Insecta: Diptera: Calyptratae) based on adult morphological characters, with special reference to the Austral species of the genus Fannia. - Invertebrate Systematics 22: 563-587.

Ebejer, M. J. \& Gatt, P. 1999: The species of Fanniidae and Muscidae of the Maltese Islands. - Studia Dipterologica 6: 79-92.

Espindola, C. B. \& Couri, M. S. 2004: Fannia flavicincta Stein (Diptera, Fanniidae), a new vector of Dermatobia hominis (Linnaeus Jr.) (Diptera, Cuterenridae). Revista Brasileira de Zoologia 21: 115-116.

Hwang, C. \& Turner, B. D. 2005: Spatial and temporal variability of Necrophagous Diptera from urban to rural areas. - Medical and Veterinary Entomology 19: 379-391.

Holloway, B. A. 1984: Larvae of New Zealand Fanniidae (Diptera: Calyptrata). - New Zealand Journal of Zoology 11: 239-258.

Kutty, S. N., Pape, T., Pont, A. C., Wiegmann, B. M. \& Meier, R. 2008: The Muscoidea (Diptera: Calyptratae) are paraphyletic: evidence from four mitochondrial and four nuclear genes. - Molecular Phylogenetics and Evolution 49: 639-652.

Kutty, S. N. Pape, T., Wiegmann, B. M. \& Meier, R. 2010: Molecular phylogeny of the Calyptratae (Diptera: Cyclorrhapha) with an emphasis on the superfamily
Oestroidea and the position of Mystacinobiidae and McAlpine's fly. — Systematic Entomology 35: 614 635.

Matuszewski, S., Bajerlein, D., Konwerski, S. \& Szpila, K. 2010: Insect succession and carrion decomposition in selected forests of Central Europe. Part 2: Composition and residency patterns of carrion fauna. - Forensic Science International 195: 42-51.

Miralbes, M. C. 2002: Estudio de la entomofauna asociada a cadáveres en el Alto Aragón (España). - Monografías S.E.A. vol. 6, Zaragoza. 94pp. [In Spanish]

Pont, A. C. \& Báez, M. 2002: Fanniidae. - In: Carles-Tolrá, M. (ed.), Catálogo de los Diptera de España, Portugal y Andorra (Insecta) Vol 8: 206. Monografías S.E.A., Zaragoza. 323 pp.

Pont, A. C. 2004: Fanniidae. - In: Pape, T. \& Beuk, P. (eds.), Fauna Europaea: Diptera. Fauna Europaea version 2.4, Available from: http://www.faunaeur.org/ (Site visited on 12 March, 2012).

Pont, A. C. \& Vikhrev, N. 2009: A new species of Fannia Robineau-Desvoidy (Diptera: Fanniidae) from the Altai Mountains, Western Siberia, Russia. - Russian Entomological Journal 17: 321-323.

Prado e Castro, C. \& García, M. D. 2010: Additions to the Piophilidae (Diptera) fauna from Portugal, with new records. - Graellsia 66: 101-105.

Prado e Castro, C., Chichorro, D., Serrano, A. \& Garcia, M. D. 2009: A modified version of Schoenly trap for collecting sarcosaprophagous arthropods. Detailed plans and construction. - Anales de Biologia 31: 1-6.

Prado e Castro, C., Arnaldos, M. I. \& García, M. D. 2010a: Additions to the Calliphoridae (Diptera) fauna from Portugal, with description of new records. - Boletín Asociación española de Entomología 33: 425-437.

Prado e Castro, C., García, M. D., Arnaldos, M. I. \& González-Mora, D. 2010b: Sarcophagidae (Diptera) attracted to piglet carcasses including new records for Portuguese fauna. - Graellsia 66: 285-294.

Rozkošný, R., Gregor, F. \& Pont, A. C. 1997: The European Fanniidae (Diptera). - Acta scientiarum naturalium Academiae scientiarum Bohemicae - Brno 31: $1-80$.

Rudzinski, H. G. 2003: Fannia conspecta sp. nov. - eine neue Fanniiden-Art der canicularis-Verwandtschaftsgruppe aus Deutschland (Diptera, Fanniidae). — Entomofauna 24: 153-156.

Tantawi, T. I., El-Kady, E. M., Greenberg, B. \& El-Ghaffar, H. A. 1996: Arthropod succession on exposed rabbit carrion in Alexandria, Egypt. — Journal of Medical Entomology 33: 566-580.

Tullis, K. \& Lee Goff, M. 1987: Arthropod succession in exposed carrion in a tropical rainforest on O'ahu Island, Hawai'i. - Journal of Medical Entomology 24: 332-339.

Quiroga, N. I. \& Domínguez, M. C. 2010: Anew species of the genus Fannia Robineau-Desvoidy (Diptera: Fanniidae) belonging to the canicularis species group, collected on pig carrion in the Yungas of the province of Jujuy, Argentina. - Studies on Neotropical Fauna and Environment 45: 95-100. 
Wang, M. F., Wang, R. R., \& Xue, W. Q. 2007a: A review of the lucidula-subgroup of the Fannia canicularis species-group (Diptera: Fanniidae). — Zoological Studies 46: 129-134.

Wang, M. F., Zhang, D. \& Xue, W. Q. 2007b: A review of the canicularis group of Fannia Robineau-Desvoidy (Diptera: Fanniidae) from China. — Oriental Insects 41: 339-350.

Wendt, L. D. \& Carvalho, C. J. B. 2007: Taxonomia de Fanniidae (Diptera) do sul do Brasil-I: nova espécie e chave de identificação de Euryomma Stein. — Revista Brasileira de Entomologia 51: 197-204. [In Portuguese]

Wendt, L. D. 2010: New species and new records of Fannia Robineau-Desvoidy (Diptera, Fanniidae) from the Brazilian Amazon Region. - Zootaxa 2578: 38-48.

Zumpt, F. 1965: Myiasis in Man and Animals in the Old World: A Textbook for Physicians, Veterinarians and Zoologists. - Butterworths, London. XV + 267 pp. 